Int. J. Electrochem. Sci., 15 (2020) 8229 - 8240

\title{
Effect of Sodium Tungstate on the Corrosion Behavior of Fe- Base Alloy in $\mathrm{H}_{2} \mathrm{SO}_{4}$ Solution
}

\author{
Ghalia A. Gaber ${ }^{1}$,Hayam. A. Aly ${ }^{2,3}$, Lamiaa Z. Mohamed ${ }^{4, *}$ \\ ${ }^{1}$ Department of Chemistry, Faculty of Science (Girls), Al-Azhar University, P.O. Box: \\ 11754, Yousef Abbas Str., Nasr City, Cairo, Egypt \\ ${ }^{2}$ Department of Metallurgical and Materials Engineering, Faculty of Petroleum and Mining \\ Engineering, Suez University, P.O. Box 43721, Suez, Egypt \\ ${ }^{3}$ Central Metallurgical Research and Development Institute (CMRDI), P.O. Box 11421, Helwan, \\ Egypt \\ ${ }^{4}$ Mining, Petroleum and Metallurgical Engineering Department, Faculty of Engineering, Cairo \\ University, Egypt \\ *E-mail: lamiaa.zaky@cu.edu.eg
}

doi: $10.20964 / 2020.08 .19$

Received: 5 March 2020 / Accepted: 30 April 2020 / Published: 10 July 2020

The corrosion behavior of Fe-base alloy in $\mathrm{H}_{2} \mathrm{SO}_{4}$ acid at different concentrations was evaluated. The effect of sodium tungstate inhibitor on Fe-base alloy in $10 \% \mathrm{H}_{2} \mathrm{SO}_{4}$ solutions was evaluated by using weight loss and potentiodynamic polarization methods along with scanning electron microscope and energy dispersive $x$-ray analysis. The corrosion rate and surface morphology of Fe-base alloy in the presence of various concentrations of sodium tungstate inhibitor compared to control in $10 \% \mathrm{H}_{2} \mathrm{SO}_{4}$ solutions were measured. The sodium tungstate inhibitor was found to improve the protection against corrosion in comparison to the uninhibited $10 \% \mathrm{H}_{2} \mathrm{SO}_{4}$ solution.

Keywords: Corrosion; Protection; Inorganic inhibitor; Electrochemical technique; Microstructure

\section{$\underline{\text { FULL TEXT }}$}

(C) 2020 The Authors. Published by ESG (www.electrochemsci.org). This article is an open access article distributed under the terms and conditions of the Creative Commons Attribution license (http://creativecommons.org/licenses/by/4.0/). 